Jerzy Dzieciuchowicz

\title{
Usługi zanikające w przestrzeni wielkomiejskiej - przykład centrum Łodzi
}

Transformacja społeczno-gospodarcza w Polsce po 1989 r. wiąże się z dynamicznym rozwojem i przemianami strukturalnymi sektora usługowego wielkich miast. Dzięki swobodzie gospodarczej w przestrzeni wielkomiejskiej pojawiło się wiele nowych rodzajów usług. Z drugiej strony doszło do upadku różnych firm usługowych, przy czym równocześnie zanikały określone, związane z nimi zawody. Procesy te były widoczne nie tylko w dużych, ale również w mniejszych miastach i na wsi.

Problematyka tej pracy dotyczy usług zanikających w przestrzeni wielkomiejskiej, rozpatrywanych na przykładzie centrum Łodzi. Przedmiotem badań jest lokalizacja i funkcjonowanie tego rodzaju usług oraz zachowania zakupowe i przestrzenne ich odbiorców. Rozpatrywane działalności zostały wytypowane w badaniach sondażowych, obejmując czyszczenie i renowację odzieży, gorseciarstwo, krawiectwo miarowe, modniarstwo, szewstwo i zegarmistrzostwo. Badania terenowe zostały przeprowadzone w latach 2012-2013 w 15 dostępnych dla celów badawczych placówkach świadczących wymienione usługi. Chodzi tutaj o placówki, których właściciele wyrazili zgodę na udział w wywiadach kwestionariuszowych i swobodnych oraz udzielanie dodatkowych informacji. Placówki te są położone w śródmieściu Łodzi, w granicach jednostki osiedlowej Centrum (ryc. 1). Uwidacznia się tam szczególnie silna koncentracja różnych rodzajów działalności usługowej. Podmiot badań stanowiły zanikające placówki usługowe, ich właściciele i klienci. Analizie zostały poddane również budynki, w których zlokalizowano takie placówki, wraz z ich najbliższym otoczeniem. Cel pracy stanowi określenie warunków i mechanizmów funkcjonowania usług zanikających w przestrzeni wielkomiejskiej oraz specyficznych właściwości struktury demograficzno-społecznej i zachowań ich odbiorców. 
W tej pracy wykorzystane zostały opublikowane opracowania, omawiające rolę i rozwój usług w warunkach rynkowych, ich klasyfikację oraz poziom rozwoju i jego zróżnicowanie przestrzenne w Polsce (Daszkowska 2008, Ilnicki 2009, Rudawska 2009; Mikołajczyk, Stolecka 2009), a także w samej Łodzi (Dzieciuchowicz 2005, 2012, 2013). Odwołano się również do opracowań poświęconych marketingowi usług (Kramer 2000, Czuba 2001, Boguszewska-Kreft 2009, Szromik 2010; Williams, Mullin 2011) i zachowaniom konsumentów (Mazurek-Łopacińska 2003; Światowy 2006, Woś, Rachocka, Kasperek-Hoppe 2011, Rudnicki 2012). Konieczne były odniesienia do prac dotyczących lokalizacji usług (Szulce 1998, Budner 1999, 2004; Godlewska 2001, 2005; Wieloński 2004, Wilk 2001). Do szczegółowej analizy badanych usług i zawodów ginących w Polsce szczególnie przydatne były prace omawiające różne ich rodzaje (Janczak, Kasprzak 2008; Skuza 2012), w tym zwłaszcza odnoszące się do samego zegarmistrzostwa (Mrugalski 2011), czyszczenia i renowacji odzieży (Sadowski 1997) i skórnictwa (Turnau 1983). Odniesienia historyczne dotyczące omawianych usług umożliwiły przede wszystkim dzieła monograficzne, traktujące o Łodzi i jej dziejach (Baranowski, Fijałek 1980; Liszewski 2009).

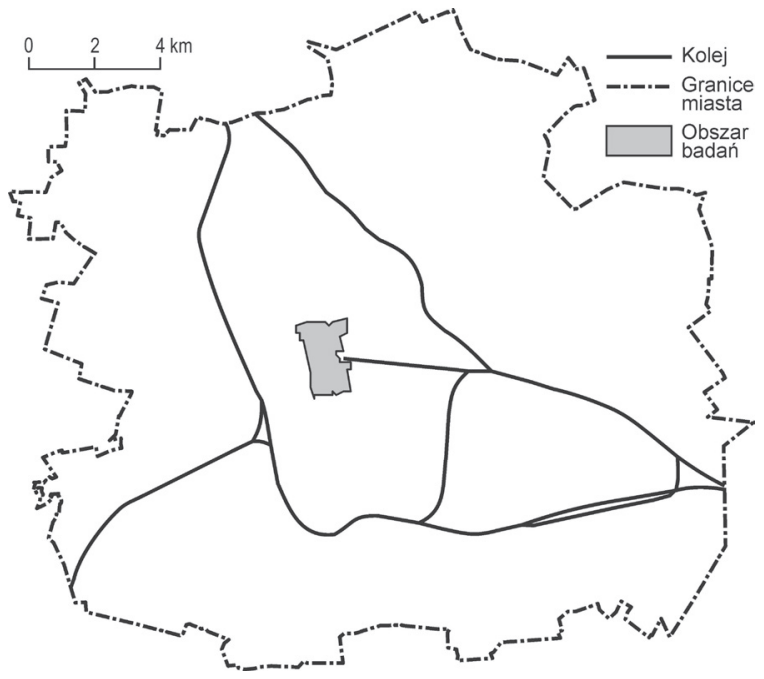

Ryc. 1. Położenie obszaru badań w Łodzi Źródło: opracowanie własne

W tym opracowaniu wykorzystano zarówno materiały dokumentacyjne, jak i dane pochodzące $z$ badań terenowych. Do pierwszej grupy materiałów należy dokumentacja prawna, opracowania kartograficzne i geodezyjne, dane statystyki publicznej, materiały udostępnione przez 
właścicieli określonych punktów usługowych i in. Drugą grupę reprezentują materiały zebrane $\mathrm{w}$ toku badań terenowych (Banaś 2013). Należy tu wymienić przede wszystkim wywiady kwestionariuszowe i swobodne z właścicielami badanych zakładów rzemieślniczych, ankiety z ich klientami, a także inwentaryzację danych punktów usługowych i ich najbliższego sąsiedztwa.

\section{Pojęcie i rodzaje usług zanikających}

Kluczowe w tej pracy pojęcie usług zanikających oznacza działalności usługowe, które cechuje powolny upadek. Łączy się z tym nie tylko likwidacja określonych placówek usługowych oraz związanych z nimi miejsc pracy, lecz także ginięcie niektórych zawodów i specjalności. Główną przyczyną zanikania takich placówek jest malejący popyt na świadczone przez nie usługi, wynikający z postępu technicznego i technologicznego oraz rosnącej konkurencji innych firm usługowych lub zakładów produkcyjnych, a także ewolucji potrzeb, upodobań i preferencji klientów. Niektóre z takich usług ograniczają się obecnie do wykonywania przez usługodawcę niestandardowych przedmiotów na ściśle określone zamówienie usługobiorcy (np. ubrań, butów, kapeluszy). Sporadycznie w tego rodzaju zakładach rzemieślniczych można też kupić od ręki gotowe wyroby. Częstokroć rozważane usługi polegają w całości lub części na odpowiednio ukierunkowanym oddziaływaniu na gotowy wyrób, wyprodukowany w zakładach przemysłowych (np. czyszczenie i renowacja odzieży, szewstwo, zegarmistrzostwo). Rezultat świadczonych usług zanikających można w znaczeniu marketingowym określić zarówno mianem produktu materialnego, jak i niematerialnego (Czuba 2001).

Wraz z upadkiem niektórych usług, jak twierdzą badacze z Uniwersytetu w Oksfordzie, w ciągu najbliższych 10-20 lat zaniknie aż 700 zawodów niewymagających dużych kwalifikacji (Danton, PAP 2014-08-06; http://metromsn.Gazeta.pl 2014-09-10). Przyczyni się do tego coraz częstsze zastępowanie usług przez automaty i roboty, które funkcjonują przez całą dobę, udoskonalane dzięki współczesnym badaniom nad automatyzacją, robotyką i sztuczną inteligencją. W USA najbardziej zagrożone są stanowiska recepcjonisty, ochroniarza, kucharza (przygotowywanie fast foodów), sprzedawcy i taksówkarza. Dla odmiany zanikanie nie zagraża tam w szczególności zawodom wymagającym pracy manualnej lub kontaktu emocjonalnego z usługobiorcą (np. zawód lekarza, artysty, księdza).

Badania prowadzone przez M. Bitnera, R. Starościka i P. Szczerbę (DAC, Czy robot zabierze ci pracę? Nesweek 1-7.12.2014: 4) wskazują na szereg stanowisk i specjalności zagrożonych automatyzacją pracy w dwóch 
najbliższych dekadach w krajach europejskich. Branże najbardziej zagrożone pod tym względem są związane $\mathrm{z}$ przetwórstwem spożywczym i administracją a zanikające zawody to przede wszystkim zawód kasjera, górnika, montera, ochroniarza, odlewnika, spawacza, kowala, kucharza i kierowcy. Regionem przodującym w rozwoju automatyzacji pracy i tym samym zanikaniu zawodów jest Europa Środkowo-Wschodnia, w tym zwłaszcza Polska, Węgry i Słowacja (ok. 35\% miejsc pracy). Niewiele słabiej automatyzacja rozwija się we Włoszech, w Hiszpanii i Portugalii. Za najmniej podatne na automatyzację uznaje się zawody i stanowiska, które wymagają oryginalności, kreatywności i zręczności. W grę wchodzą tutaj przede wszystkim stanowiska kierownicze, specjalistów w zakresie prawa, sprzedaży, finansów, marketingu i PR, a także analityków, programistów, nauczycieli, lekarzy, fryzjerów i kosmetyczek. Inwazja robotów będzie rozwijać się najwolniej w bogatych krajach Europy północnej i Szwajcarii (17-18\% miejsc pracy).

Zanikania krawiectwa miarowego i szewstwa w Polsce dowodzi badanie opinii publicznej, przeprowadzone przez CBOS w 2005 r., które dotyczyło preferowanych miejsc zakupu ubrań, bielizny i butów (http:// www.cbos.pl/ SPISKOM/2005/K_125_05). W badaniu tym jedynie $1 \%$ ankietowanych deklarowało, że rzeczy szyte na miarę zazwyczaj kupu198 ją u krawca lub szewca, dość często - 3\%, natomiast aż 77\% nigdy nie dokonywało tam tego typu zakupów. Tymczasem wskazane towary były kupowane zazwyczaj lub dość często w specjalistycznych sklepach przez $43 \%$ respondentów.

Specyficzne rodzaje usług i zawodów ginących cechują od dawna tereny wiejskie, podlegające urbanizacji. W Polsce na obszarach wiejskich uwidacznia się zróżnicowanie regionalnie wielu rzemiosł, które należałoby ocalić od zapomnienia. Rzemiosła te mają bogatą tradycję, ukształtowaną $\mathrm{w}$ warunkach znacznej samowystarczalności i samozaopatrzenia gospodarstwa wiejskiego, przy czym zanikają one w szczególności pod wpływem rozwoju przemysłu (Skuza 2012). Są kojarzone z dość szerokim spektrum zawodów (24), związanych głównie z pięcioma następującymi dziedzinami działalności:

- budownictwem: ciesielstwo, dekarstwo, stolarstwo;

- gospodarstwem: obróbka drewna, bednarstwo, kołodziejstwo, plecionkarstwo, sitarstwo, garncarstwo, kowalstwo, torfiarstwo, rymarstwo;

- wytwarzaniem ubrań: tkactwo, krawiectwo i szewstwo;

- przygotowaniem pożywienia: młynarstwo, wypiek chleba, bartnictwo i pszczelarstwo;

- pozycją i autorytetem w środowisku lokalnym: obróbka bursztynu, hafciarstwo, koronkarstwo, fajkarstwo, wytwarzanie wyrobów z rogu i zabawkarstwo. 


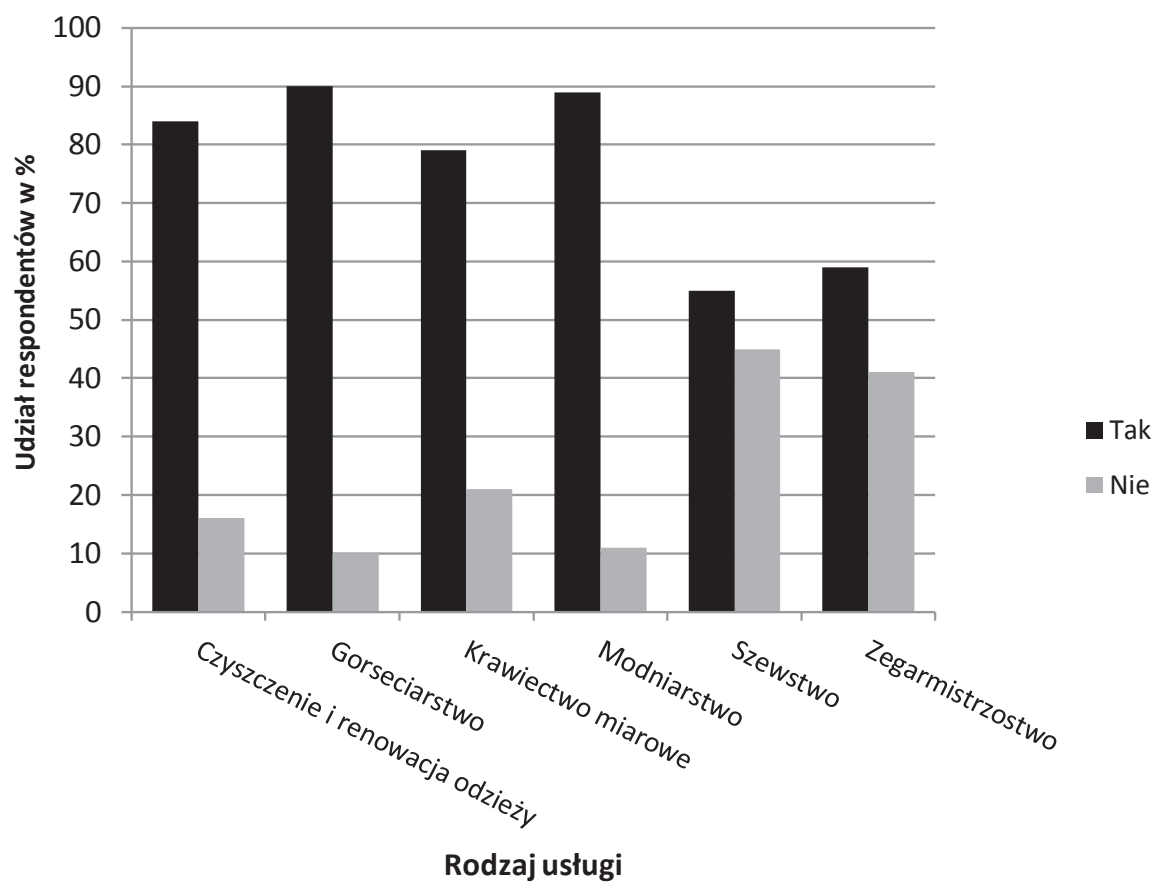

Ryc. 2. Przynależność badanych usług do zanikających w opinii respondentów Źródło: materiały zebrane przez J. Banaś (2013); opracowanie własne

Cała ta sfera dziedzictwa narodowego w powiązaniu z rozwojem turystyki może w przyszłości stymulować rozwój ekonomiczny zacofanych obszarów wiejskich.

Do szczegółowej analizy wytypowano sześć rodzajów usług zanikających, wskazanych (przez ponad 50\% ankietowanych) w badaniach sondażowych przez mieszkańców Łodzi (100 respondentów), tj. czyszczenie i renowacja odzieży, gorseciarstwo, krawiectwo miarowe, modniarstwo, szewstwo, zegarmistrzostwo (ryc. 2). Usługi te w uproszczeniu zostały zdefiniowane następująco:

- czyszczenie i renowacja odzieży to działalność polegająca na jej praniu wodnym lub chemicznym usuwaniu z niej zabrudzeń i plam oraz farbowaniu i naprawie;

- gorseciarstwo jest to zajęcie polegające na szyciu gorsetów, biustonoszy i pasów do pończoch;

- krawiectwo miarowe oznacza szycie z tkanin i dzianin odzieży (bielizny) na miarę, a także jej naprawianie i przerabianie;

- modniarstwo jest utożsamiane $\mathrm{z}$ wyrobem i sprzedażą damskich kapeluszy i ręcznie wyrabianych woalek oraz ozdób i dodatków do sukienek; 
- szewstwo to wyrób i naprawa obuwia;

- zegarmistrzostwo to rzemiosło zajmujące się naprawą i konserwacją zegarów i zegarków, zazwyczaj połączoną z ich sprzedażą. Do poł. XIX w. obejmowało również wytwarzanie zegarów.

Warto przy tym odnotować dość duży udział respondentów stojących na stanowisku, iż szewstwo (45\% respondentów) i zegarmistrzostwo (41\%) nie należy do kategorii usług zanikających. Jednocześnie stosunkowo nieliczni respondenci proponowali, aby włączyć do usług zanikających takie działalności, jak: kaletnictwo, bednarstwo, ślusarstwo, cerowanie artystyczne, czyszczenie dywanów, czyszczenie pierza, introligatorstwo, kowalstwo artystyczne, maglownictwo, tapicerstwo, tokarstwo, rymarstwo i zduństwo.

Zgodnie z Polską Klasyfikacją Działalności (2007), rozpatrywane usługi należą do sekcji S, w której wydzielono pozostałą działalność usługową. Odrębny, interesujący przypadek niejednoznacznego miejsca w analizowanej klasyfikacji reprezentuje zegarmistrzostwo, które współcześnie nabrało - jak się wydaje - głównie charakteru handlowego.

Badane usługi są zaliczane do usług rynkowych, gdyż rządzą nimi mechanizmy rynkowe i specyficzne sposoby dystrybucji, kształtujące ich ceny. Mają one charakter dóbr prywatnych nabywanych odpłatnie z do-

200 chodów osobistych ludności w warunkach swobodnego wyboru. Są przy tym wykonywane w sposób zorganizowany i ciągły (Dzieciuchowicz 2005). Wszystkim tym usługom odpowiadają specyficzne zawody wykonywane przez pracujących w danych zakładach rzemieślniczych. Warto również zauważyć, że kategoria usług ginących mieści się w wyróżnianej m.in. przez Katouziana grupie usług starych, które cieszyły się szczególną popularnością w okresie preindustrialnym (Rudawska 2009).

Na funkcjonowanie badanych usług istotny wpływ wywierają różne regulacje prawne, dotyczące prowadzenia działalności gospodarczej. Szczególne znaczenie ma w tym przypadku ustawa z dnia 4 marca 2010 r. o świadczeniu usług na terytorium Rzeczypospolitej Polskiej.

\section{Rozwój historyczny badanych usług}

Każdy z rozpatrywanych rodzajów usług ma swoją własną, odrębną historię. Biorąc pod uwagę czyszczenie i konserwację odzieży, warto zauważyć, że już czasach starożytnych stosowane były proste sposoby prania odzieży z tkanin, a także konserwacji odzieży ze skóry zwierzęcej (Sadowski 1997). Najstarszą metodą zabezpieczania takiej skóry przed procesem gnilnym było jej przydymianie, natomiast do zmiękczania, konserwacji i farbowania skóry stosowano tłuszcze zwierzęce oraz ekstrakty 
z liści i kory określonych drzew. Niektórych z tych metod używa się jeszcze obecnie. Nowoczesne czyszczenie wyrobów tekstylnych, którym zajmują się rozpatrywane zakłady rzemieślnicze i pralnie, obejmuje zarówno czyszczenie chemiczne, jak i pranie wodne, a także usługi podnoszące walory użytkowe odzieży (apretura, impregnacja) i usługi uzupełniające (np. poprawki krawieckie). Czyszczeniu i praniu podlegają w głównej mierze spodnie, spódnice, suknie, koszule, krawaty, płaszcze, ale również pościel, zasłony, koce i dywany. Na czyszczenie i renowację odzieży skórzanej składają się takie zabiegi, jak korekta kolorów, nabłyszczanie, warsowanie, nakładanie pigmentu, impregnacja, utrwalanie efektów itp. Większość tych czasochłonnych prac jest wykonywana ręcznie. Po II wojnie światowej zakres takich usług został ograniczony m.in. z uwagi na masową produkcję dla potrzeb gospodarstw domowych pralek mechanicznych, systematycznie udoskonalanych, napędzanych silnikiem elektrycznym.

Początki gorseciarstwa sięgają średniowiecza (Janczak, Kasprzak 2008). W celu wysmuklenia sylwetki kobiecej wprowadzono wtedy zakryte gorsety, sięgające od ramion do pasa, które były wiązane na plecach i wzmacniane prętami drewnianymi lub metalowymi. Nieco później używano mniej zakrytych gorsetów uwypuklających biust, zastąpionych w XIX w. przez sztywniejsze i dłuższe gorsety, które modelowały gors i talię, co mogło nawet doprowadzić do uszkodzenia narządów wewnętrznych. Zauważmy też, że niemożliwe było samodzielne wiązanie takich gorsetów. Tym niemniej kobiety przestały używać ich dopiero podczas I wojny światowej. W 1914 r. opatentowany został przez M. P. Jacob biustonosz podobny do współczesnego, który składał się z dwóch chustek do nosa, obszytych kolorową wstążką. Udoskonalono go później, wprowadzając przy tym różne rozmiary miseczek.

Zajęciem znanym od dawna jest krawiectwo. W warunkach polskich stało się ono samodzielnym zawodem w XIV w. (Skuza 2012). Na rosnącą popularność krawiectwa wpłynęły niskie koszty wyposażenia odpowiedniego warsztatu i duże zapotrzebowanie na tego rodzaju usługi. Specjalizacje krawieckie, takie jak krawiectwo męskie i damskie, czy też lekkie (szycie bluzek, sukienek i spodni) i ciężkie (szycie płaszczy i palt), zaczęły się wyodrębniać na przełomie XVI i XVII w. Wówczas pojawiły się również pierwsze wzorniki z wykrojami ubrań. Rozwój krawiectwa był wtedy ograniczony, ponieważ większość prac krawieckich wykonywano ręcznie przy użyciu igły. Zakres i jakość usług krawieckich wzrosły dopiero wydatnie, gdy w zakładach krawieckich, począwszy od II połowy XIX w., zaczęto stosować maszyny do szycia $\mathrm{z}$ napędem nożnym, a po II wojnie światowej z silnikiem elektrycznym. Na początku XX w. i w latach międzywojennych rozwinęło się krawiectwo objazdowe. Warto też zauważyć, 
że prowadzenie zakładu krawieckiego w mieście zazwyczaj dawało większe dochody aniżeli na wsi. Współcześnie masowa produkcja przemysłowa odzieży i bielizny warunkuje systematyczne zmniejszanie się liczby zakładów krawieckich. Jednakże ostatnio, gdy zakładów tych zostało już niewiele, wśród młodych, dobrze zarabiających mężczyzn zaczyna powracać moda na garnitury szyte na miarę. Koszt takiego garnituru z dobrego materiału może dochodzić nawet do 10 tys. zł, a czas wykonania sięga sześciu miesięcy.

Długą historię ma modniarstwo, o czym świadczy fakt, że już w starożytności Grecy (V w. p.n.e.) używali kapeluszy z szerokim rondem (petasos), wykonywanych z filcu. Kształt i wielkość kapeluszy stopniowo ewoluowały, a ich użycie upowszechniło się w XVIII w. W miarę upływu czasu powstało kilka różnych modeli kapeluszy męskich i damskich. W końcu XVIII stulecia zamożniejsi mężczyźni zaczęli używać czarnego, atłasowego cylindra, który reprezentuje wysoki, sztywny kapelusz z walcowatą główką i wąskim rondem odgiętym z boków ku górze. Jego składaną na płasko - dzięki wmontowanym sprężynom - odmianę stanowił dwurożny szapoklak. Jednocześnie dość popularny stał się mniejszy i niezbyt formalny melonik, będący sztywnym kapeluszem o zaokrąglonej główce i wąskim, lekko podgiętym rondzie. Natomiast na początku 202 XX w. pojawiła się fedora, będąca miękkim filcowym kapeluszem z szerokim opadającym rondem. Na lato przeznaczony był słomkowy kapelusz z płaską główką i szerokim rondem, nazywany panamą. Był on wyplatany z liści południowo-amerykańskiej palmy. Nieco później mężczyźni zaczęli korzystać ze sztywnych czapek (kaszkiet) - o osiemnastowiecznym wojskowym rodowodzie $-\mathrm{z}$ daszkiem $z$ przodu i okragłym denkiem lub z podwiniętym daszkiem z przodu i z tyłu, a jedynie $\mathrm{w}$ wyjątkowo uroczystych okazjach z cylindrów. Dla kobiet na początku XIX w. przeznaczone były delikatne kapelusze ozdobione sztucznymi kwiatami lub wstążkami, zastąpione później przez duże i ciężkie nakrycia głowy. $\mathrm{Z}$ kolei $\mathrm{w}$ latach 60 . XIX w. modne stały się małe kapelusiki, przypinane do włosów lub zapinane pod szyją. W końcu XIX w. ponownie wróciła moda na bogato zdobione kapelusze, z piórami lub kwiatami. Dla odmiany, w latach 20. XX w. kobiety zaczęły nosić małe toczki. Obecnie występują one w nieco zmienionej formie niewielkich stroików, mocowanych bezpośrednio do włosów. Jednakże w użyciu zarówno wśród dzieci, jak i dorosłych są najczęściej miękkie, wełniane lub bawełniane czapki bez daszka. Dodajmy, że modniarstwo pozostaje zawodem typowo żeńskim (modystki, modniarki).

Jeszcze dłuższą historią - w porównaniu z modniarstwem - wyróżnia się szewstwo (Janczak, Kasprzak 2008). Dowodzi tego chociażby fakt, że sandały z papirusu, pochodzące jeszcze z II tysiąclecia p.n.e., zostały 
znalezione w egipskich grobowcach. Jednakże szewstwo, jako działalność usługowa, wyodrębniło się w Europie dopiero w VIII w. n.e. Wytwarzane były różne rodzaje obuwia. Buty wieloczęściowe, złożone z cholewki i podeszwy, wykonywano z reguły z różnych rodzajów skór. Buty wiązane, początkowo o zaokrąglonym nosku, weszły do użycia w $X$ w. Obuwie $\mathrm{z}$ ostrym, wydłużonym noskiem pojawiło się w XII w. Warto przy tym zauważyć, że długość noska zależała od statusu społecznego (Turnau 1983). W Polsce w wieku XVI i XVII doszło do specjalizacji szewstwa. Wyrobem tanich butów zajmowali się zwykli szewcy, natomiast kurdybanicy i safianicy wytwarzali buty z drogich materiałów - kurdybanu, tj. skóry koźlej, cielęcej i jagnięcej, wytłaczanej lub malowanej i złoconej, oraz safianu, czyli skóry koziej (Skuza 2012). Rozwój szewstwa, uzależniony od koniunktury gospodarczej, doprowadził do tego, że uzyskało ono rangę jednego $\mathrm{z}$ najpopularniejszych rzemiosł $\mathrm{w}$ miastach i na wsi. W XX w. produkcja obuwia stała się domeną dużych fabryk obuwniczych, a ich konkurencja przyczyniła się do ograniczenia usług szewskich głównie do napraw używanego obuwia. Obecnie szewstwo jest zawodem o dość niskim prestiżu, wykonywanym niemal wyłącznie przez mężczyzn.

Bogatą tradycją może się poszczycić również zegarmistrzostwo (Mrugalski 2011). Jego intensywny rozwój został zainicjowany na przełomie XIV i XV w. w Europie Zachodniej: Anglia, Francja, Niemcy i Holandia. Rzemiosło to podlegało zmianom pod wpływem postępu technicznego w budowie zegarów. Antenatem współczesnych zegarów były, znane już w starożytności w Egipcie, Babilonii, Grecji i Rzymie, najpierw zegary słoneczne (gnomony), a później zegary wodne, ogniowe oraz klepsydry piaskowe. W średniowiecznej Europie zainicjowano budowę zegarów mechanicznych, pozwalających na ciągłe odmierzanie czasu. Pierwszy taki zegar - z obciążnikiem i mechanizmem bicia - zbudował francuski zakonnik Gebert z Aurillac (późniejszy papież Sylwester II) ok. 1000 r. Zegary wieżowe, które wybijały godziny i miały jedynie jedną wskazówkę, pojawiły się w XIV w. Z kolei, około 1510 r. ślusarz P. Henlein z Norymbergii wynalazł zegarek przenośny ze sprężyną do napędu chodu i cylindryczną obudową. W 1657 r. Ch. Huygens, wykorzystując prawa ruchu wahadłowego odkryte przez Galileusza (1637 r.), zbudował pierwszy zegar wahadłowy. Później (1675 r.) wprowadził sprężynkę balansu (spiralny włos), co pozwoliło na wzrost dokładności zegarów i zastosowanie wskazówki minutowej. W 1839 r. A. Patek i F. Czapek w Genewie założyli pierwsza, niewielką manufakturę produkującą zdobione zegarki kieszonkowe o skomplikowanych mechanizmach. Z kolei, w 1845 r. A. Patek wraz z A. Philippem uruchomili produkcję zegarków kieszonkowych. Dopiero na początku XX w. został upowszechniony zegarek naręczny, złożony z setek mikroskopijnych części. Z kolei, w drugiej połowie XX w. rozwinęła się 
masowa produkcja zegarów i zegarków elektrycznych i elektronicznych (kwarcowych). Współcześnie wyjątkową dokładność zapewnia zegar atomowy. Pierwszy tego typu zegar został skonstruowany w latach 19481949 przez H. Lyonsa (USA).

\section{Lokalizacja usług zanikających w śródmieściu Łodzi}

\section{Czynniki lokalizacji}

Lokalizację usług zanikających - podobnie jak innych rodzajów działalności gospodarczej - powinno się rozpatrywać zarówno z punktu widzenia walorów miejsca ich zlokalizowania w skali całego miasta i na określonej działce, jak też wymogów lokalizacyjnych przypisanych samym usługom. Za najkorzystniejszą lokalizację należy uznać miejsce, w którym walory i wymogi lokalizacyjne działalności usługowej będą najlepiej do siebie dopasowane (Wieloński 2004: 9).

Czynniki warunkujące lokalizację zanikających placówek usługowych w centrum Łodzi, wskazywane w wywiadach kwestionariuszowych z ich właścicielami (Banaś 2013), można uznać za zbieżne z wybranymi deter-

204 minantami lokalizacji małych punktów usługowych w Warszawie, zestawionymi przez W. Wilka (2001) - por. tab. 1. Najważniejsze kategorie tych czynników reprezentują dostępność komunikacyjną zanikających placówek handlowych, ich podaż, sytuację lokalową, najbliższe otoczenie i inne warunki.

Do czynników lokalizacji najczęściej przytaczanych w przeprowadzonych wywiadach należą: łatwość dojazdu klientów środkami komunikacji miejskiej lub własnym samochodem i koszty utrzymania lokalu usługowego (dzierżawa, najem). Mniejszą wagę właściciele przywiązywali do bliskości swojego miejsca zamieszkania, dostępności miejsc parkingowych dla potrzeb własnych i klientów, jak też ogólnego stanu technicznego i wyposażenia budynku, w którym znajduje się dany zakład usługowy. Natomiast najmniej istotne - zdaniem właścicieli - były takie czynniki lokalizacji danych usług, jak: bliskość dostawców i zakładów współpracujących, położenie w sąsiedztwie zakładów tej samej branży, możliwość połączenia/oddzielenia siedziby zakładu i mieszkania, planowane przez miasto inwestycje, które mogłyby zwiększyć liczbę klientów zakładu.

Zidentyfikowane czynniki lokalizacji usług zanikających mają charakter subiektywny, bowiem odzwierciedlają punkt widzenia właściciela danej placówki usługowej. Każdy właściciel ma własną opinię o lokalizacji swojego zakładu i własne wyobrażenie przestrzeni miasta. Właściciele wskazywali najczęściej kilka najważniejszych czynników lokalizacyjnych, 
których współwystępowanie w rzeczywistości może być nierealne. Niektóre ze wskazanych czynników należy traktować jedynie jako wymogi pożądane, które faktycznie nie zostały spełnione w miejscu obecnej lokalizacji określonego zakładu.

Tabela 1. Czynniki lokalizacji usług zanikających

\begin{tabular}{|c|l|}
\hline $\begin{array}{c}\text { Kategorie } \\
\text { czynników }\end{array}$ & \multicolumn{1}{c|}{ Wskazane czynniki } \\
\hline $\begin{array}{c}\text { Dostępność } \\
\text { komunikacyjna }\end{array}$ & $\begin{array}{l}\text { - łatwość dojazdu środkami komunikacji publicznej } \\
\text { - } \begin{array}{l}\text { - bliskość dojaź miejsca dla klientów dysponujących samochodem } \\
\text { - miejsce parkingowe dla klientów i pracowników }\end{array}\end{array}$ \\
\hline $\begin{array}{c}\text { Specyfika } \\
\text { podaży usług }\end{array}$ & $\begin{array}{l}\text { - bliskość dostawców, zakładów współpracujących (także możliwość kontaktów } \\
\text { osobistych i służbowych) } \\
\text { - położenie w sąsiedztwie zakładów tej samej branży } \\
\text { - brak (unikanie) konkurencji }\end{array}$ \\
\hline $\begin{array}{c}\text { Sytuacja } \\
\text { lokalowa }\end{array}$ & $\begin{array}{l}\text { - koszty utrzymania obiektu (dzierżawy, najmu) } \\
- \text { możliwość połączenia/oddzielenia siedziby zakładu i mieszkania } \\
\text { - ogólny stan techniczny budynku i jego wyposażenie }\end{array}$ \\
\hline $\begin{array}{c}\text { Najbliższe } \\
\text { otoczenie } \\
\text { zakładu }\end{array}$ & $\begin{array}{l}\text { - możliwości (przestrzenne) dalszego rozwoju zakładu } \\
- \text { reprezentacyjność otoczenia (prestiż dzielnicy, image, ,dobry adres”) } \\
\text { - walory estetyczne i ekologiczne (małe natężenie hałasu, zanieczyszczenie } \\
\text { powietrza) } \\
\text { - spokojna i bezpieczna okolica }\end{array}$ \\
\hline Inne & $\begin{array}{l}\text { - planowane inwestycje miasta (gminy), które w przyszłości mogą zwiększyć } \\
\text { liczbę klientów zakładu } \\
\text { - pozostałe czynniki }\end{array}$ \\
\hline
\end{tabular}

Źródło: opracowanie własne na podstawie (Wilk 2001), (Banaś 2013)

\section{Lokalizacja ogólna}

Badaniom podlegały usługi zanikające, zlokalizowane w śródmieściu Łodzi, na obszarze jednostki osiedlowej Centrum (obręb ewidencyjny S-1 i S-2), w której dominuje funkcja usługowa (Dzieciuchowicz 2005, 2006, 2009, 2013), przy czym placówki usługowe towarzyszą tam zwartej, bardzo intensywnej zabudowie mieszkaniowej (Dzieciuchowicz 2011). Placówki te mają wyjątkowo korzystne położenie komunikacyjne, dzięki wysokiej gęstości sieci drogowej, a także linii komunikacji tramwajowej i autobusowej, przy dużym natężeniu przewozów pasażerskich. W tych warunkach zapewniony jest łatwy dostęp klientów do badanych usług. Ponadto rozpatrywany obszar miasta wyróżnia bardzo wysoka gęstość zaludnienia (> 10000 osób na $\mathrm{km}^{2}$ ), wpływająca korzystnie na popyt na określone usługi (Dzieciuchowicz 2014). Większość analizowanych placówek usługowych 
została zlokalizowana w środkowej części Centrum (ryc. 3). Warto przy tym zauważyć, że jedynie badane zakłady szewskie skupiły się wzdłuż samej ulicy Piotrkowskiej.

\section{Lokalizacja szczegółowa}

Lokalizację szczegółową usług znikających w centrum Łodzi rozpatrywano, biorąc pod uwagę działki bezpośrednio sąsiadujące po obydwu stronach ulicy ${ }^{1} \mathrm{z}$ działką na której zlokalizowana została dana placówka usługowa (Banaś 2013). Badania inwentaryzacyjne wykazały, że w sąsiedztwie usług zanikających przeważnie występują zarówno lokale mieszkalne, jak też różnego rodzaju usługi rynkowe. Natomiast rzadko sąsiedztwo to tworzą usługi nierynkowe. Ogólnie biorąc, taki sposób zagospodarowania przestrzeni otaczającej zanikające zakłady usługowe powinien ułatwiać ich funkcjonowanie.

Rozpatrywane placówki usługowe znajdują się nie tylko w budynkach frontowych, lecz także w oficynach. Jedna z tych placówek (zakład szewski) została zlokalizowana w bramie. Oczywiście $\mathrm{z}$ natury rzeczy najkorzystniejsza jest pierwsza $\mathrm{z}$ tych trzech lokalizacji. Żadna z zanikających placówek usługowych nie zajmowała odrębnego budynku, zatem 206 wszystkie należą do kategorii usług wbudowanych.

Lokalizacja usług zanikających, w opinii ich właścicieli, ma wiele zalet i wad o różnym znaczeniu. Do najważniejszych zalet - wielokrotnie wskazywanych w wywiadach kwestionariuszowych z właścicielami - zaliczono położenie zakładu usługowego w tym samym miejscu od wielu lat, bliskie położenie przystanku komunikacji miejskiej, lokalizację zakładu w centrum miasta, usytuowanie tego zakładu we frontowej części budynku oraz bliskie sąsiedztwo parkingu. Liczniejszą kategorię tworzą mniej istotne - wymieniane $\mathrm{w}$ wywiadach tylko jednokrotnie - zalety, do których należy bliskie położenie dworca kolejowego, lokalizacja przy ul. Piotrkowskiej lub w pobliżu tej ulicy, sąsiedztwo wielu innych placówek usługowych, położenie w nowo wyremontowanym budynku, możliwość parkowania na miejscu, dobry dojazd, obniżony czynsz w przypadku lokalizacji w podwórzu. Gama wad lokalizacji omawianych usług jest bogatsza niż przytoczonych wyżej zalet. Do ważniejszych wad, wielokrotnie wskazywanych w wywiadach, należą: położenie placówki usługowej w podwórzu, jej lokalizacja na odcinku ulicy wyłączonym z ruchu, brak w zakładzie zaplecza higieniczno-sanitarnego, brak możliwości bezpośredniego dojazdu do zakładu. Liczniejsze, aczkolwiek mniej dokuczliwe

${ }^{1}$ W przypadku ulicy dwujezdniowej, ograniczającej dostępność do obiektu usługowego dla przemieszczających się po drugiej stronie, uwzględniano tylko działki sąsiadujące $\mathrm{z}$ tej samej strony. 
wady, które w wywiadach były wskazywane tylko jednokrotnie, reprezentują: zły stan techniczny budynku mieszczącego zakład usługowy, nieestetyczny wygląd tego budynku, brak w pobliżu przystanku komunikacji miejskiej, lokalizacja zakładu poza ścisłym centrum miasta, zły stan techniczny użytkowanego lokalu, wysoki czynsz związany z lokalizacją zakładu w centrum, zbyt mała powierzchnia użytkowanego lokalu, lokalizacja zakładu w bramie, brak parkingu w pobliżu zakładu, małe natężenie ruchu na ulicy, przy której znajduje się zakład.

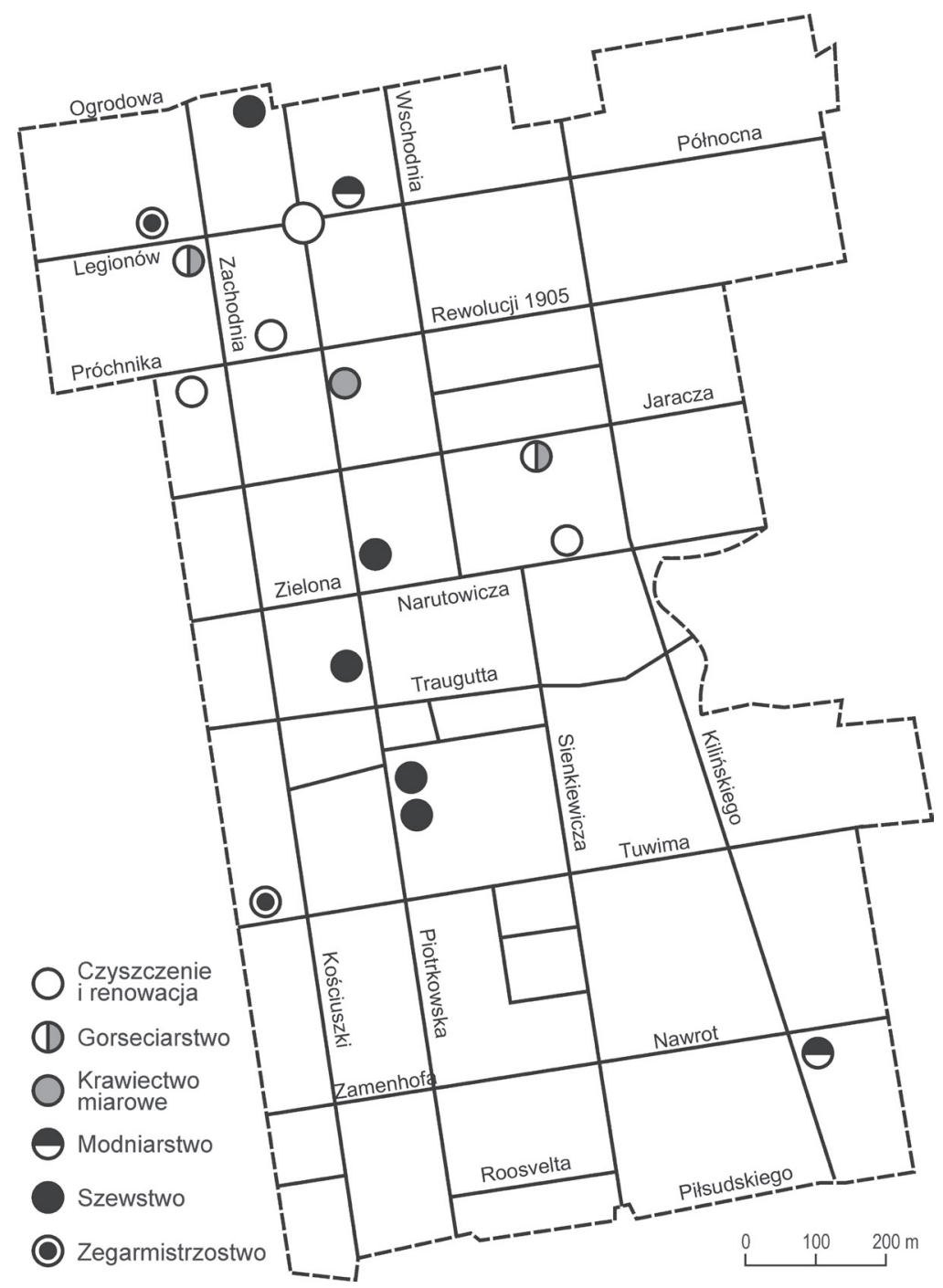

Ryc. 3. Lokalizacja badanych placówek usługowych Źródło: materiały zebrane przez (Banaś 2013); opracowanie własne 


\section{Funkcje zanikających placówek usługowych w śródmieściu Łodzi}

\section{Właściciele placówek usługowych}

Dzięki wywiadom kwestionariuszowym ustalono strukturę demograficzno-społeczną właścicieli, jak również funkcje badanych zakładów usługowych (Banaś 2013). Wśród właścicieli było ośmiu mężczyzn i siedem kobiet. Wszyscy należą wyłącznie do niemobilnej grupy wieku produkcyjnego. Charakterystyczna jest przy tym dość duża rozpiętość ich wieku (41-77 lat). Dane te wskazują na zaawansowany proces starzenia demograficznego rozpatrywanej grupy społeczno-zawodowej, który rzutuje niekorzystnie na perspektywy dalszego rozwoju omawianych usług. Zauważmy również, że zdecydowana większość właścicieli pozostawała w związkach małżeńskich. Korzystnie o kwalifikacjach respondentów świadczy fakt, że przeważnie osiągnęli średnie lub wyższe wykształcenie, a ich zawód wykonywany zazwyczaj pokrywał się z zawodem wyuczonym. Swoje firmy z reguły prowadzą samodzielnie. Ponadto wszyscy są mieszkańcami Łodzi, a ich miejsca zamieszkania znajdują się zwykle w dzielnicach pozaśródmiejskich. Przeciętna odległość dojazdów do pracy w danej grupie 208 rzemieślników nie jest duża, gdyż wynosi ok. 4 km. Tylko czterech z nich deklarowało dojazdy na odległość powyżej $6 \mathrm{~km}$.

\section{Działalność zanikających placówek usługowych}

Do różnych funkcji badanych placówek usługowych dostosowana jest ich zazwyczaj prosta aranżacja wnętrz. Zwykle placówki te zajmują lokale o niewielkiej powierzchni $\left(7-20 \mathrm{~m}^{2}\right)$, podzielone na dwa, różnej wielkości pomieszczenia (ryc. 4). Pierwsze, mniejsze, służy przyjmowaniu klientów. Często jest ono wyposażone $\mathrm{w}$ regał lub gablotę, w których eksponuje się przedmioty wyrabiane lub naprawiane w zakładzie. Na ścianie zawieszone są świadectwa czeladnicze lub mistrzowskie oraz dyplomy właściciela zakładu. Znajdują się tam również biurko lub stolik i krzesła dla klientów. Drugie, większe pomieszczenie, oddzielone od poprzedniego ścianką działową lub zasłonka, stanowi pracownia, w której wykonywane są określone usługi. W niektórych zakładach (np. gorseciarskich) wydzielone są też niewielkie przymierzalnie.

Analizowane zakłady usługowe są wyposażone $\mathrm{z}$ reguły w przestarzałe, używane od wielu lat maszyny, urządzenia i narzędzia, z których tylko nieliczne podlegały w ostatnich latach modernizacji. Jakość używanych przez te zakłady materiałów jest zróżnicowana w zależności od rodzaju działalności i wymagań klientów. Niewielka część materiałów 
pochodzi z importu. Zdecydowana większość zakładów nie zatrudnia pracowników najemnych, a tylko w niektórych zakładach okresowo, przy zwiększonej liczbie zleceń, przyjmuje się dodatkowych pracowników. Zjawiskiem niekorzystnym dla dalszego funkcjonowania tych placówek jest zaprzestanie w nich kształcenia uczniów w określonych zawodach.

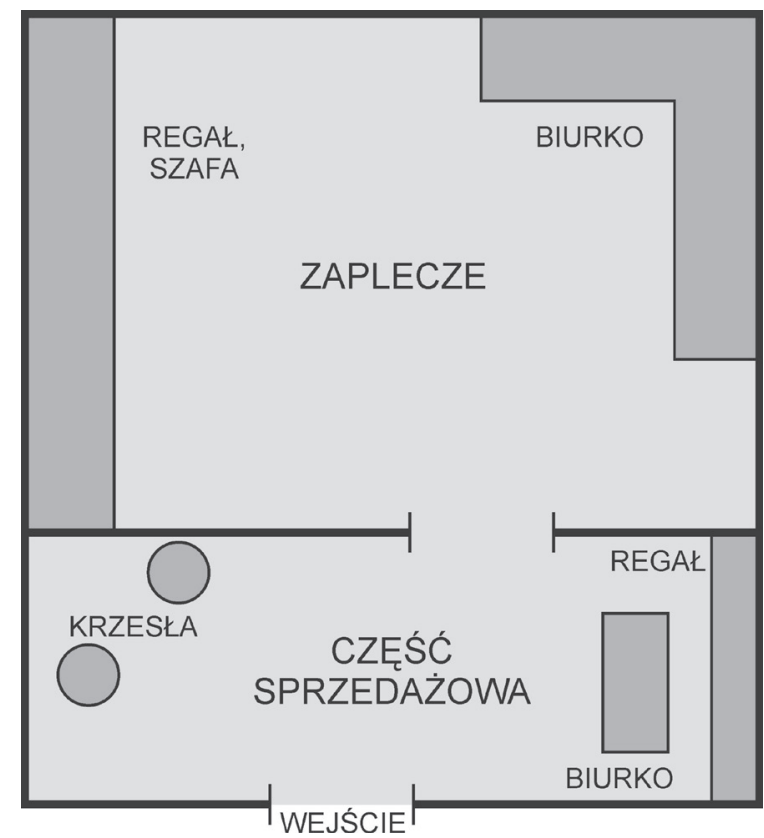

Ryc. 4. Aranżacja wnętrza typowej placówki usługowej Źródło: (Banaś 2013)

Dominującą kategorię usługobiorców rozpatrywanych zakładów usługowych reprezentują stali klienci, przy czym zjawiskiem obserwowanym powszechnie $w$ ostatnich latach jest systematyczny spadek ich liczby. W wielu przypadkach główną przyczynę tego spadku stanowi import tanich towarów ze Wschodu. Na przykład importowane biustonosze, czapki czy buty są wielokrotnie tańsze od wyrabianych w danych zakładach rzemieślniczych. Ponadto koszt naprawy takich wyrobów przewyższa cenę nowych, produkowanych w przedsiębiorstwach przemysłowych w kraju lub zagranicą. Znikomą rolę w funkcjonowaniu poszczególnych zakładów usługowych odgrywa marketing wykonywanych usług. Tylko nieliczne zakłady założyły własną stronę internetową lub fanpage na Facebooku. O działalności usługowej danych placówek informują przede wszystkim wywieszone szyldy i powielane ulotki, czasami reklamy umieszczane w Panoramie firm, a także klienci skłonni polecać świadczone usługi. 


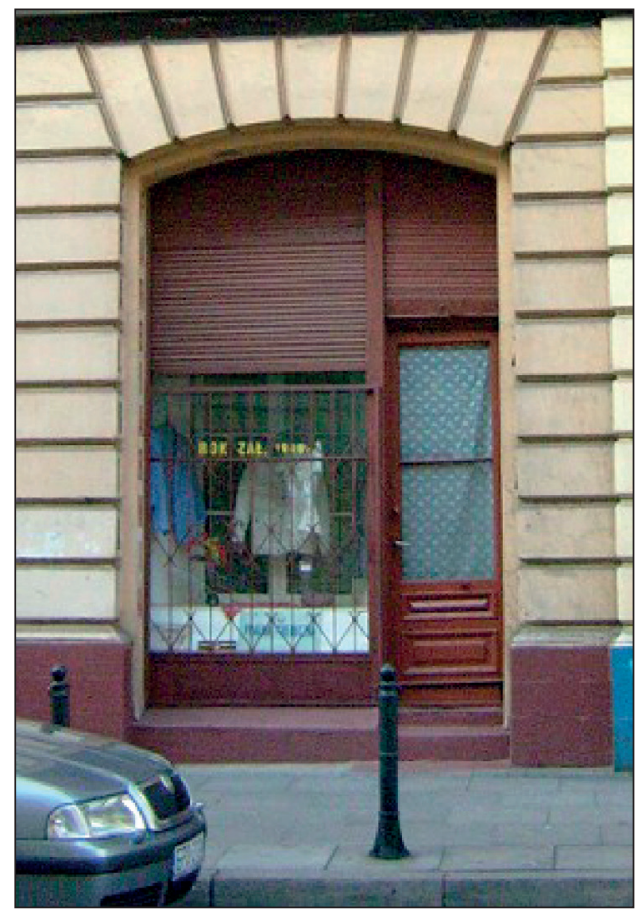

Fot. 1. Zakład chemicznego czyszczenia i farbowania (fot. autora)

Poszczególne badane placówki usługowe pełnią od wielu lat prawie te same funkcje wyspecjalizowane. Tylko w sporadycznych przypadkach ich oferta usługowa została niedawno nieco poszerzona. Wśród trzech placówek zajmujących się czyszczeniem i renowacją odzieży (fot. 1) jedna specjalizuje się w czyszczeniu i farbowaniu kożuchów i skór metodą garbarską oraz czyszczeniu i farbowaniu zamszu. Drugi zakład wykonuje tylko chemiczne czyszczenie i farbowanie tkanin. Natomiast w trzecim zakładzie świadczone usługi obejmują czyszczenie skór, kożuchów i futer oraz drobne naprawy i przeróbki odzieży. Obydwie pracownie gorseciarskie zajmują się miarowym szyciem biustonoszy, gorsetów i kostiumów plażowych oraz pasów, a także staników dla tzw. amazonek i staniczków korygujących krzywiznę pleców lub łopatek. Ponadto wykonują one również poprawki gotowych biustonoszy i bielizny. Pracownia krawiectwa miarowego szyje wyłącznie odzież męską w szczególności garnitury i smokingi. Dwa zakłady modniarskie różnią się nieco zakresem świadczonych usług. Jeden z nich wyrabia i naprawia kapelusze filcowe, czapki materiałowe oraz nakrycia głowy ze skór naturalnych (lisów, norek), a także kapelusze słomkowe. Nakrycia te są wykonywane w sposób tradycyjny, przy zastosowaniu drewnianej formy, z materiałów sprowadzanych 
głównie z Włoch. Niektóre nakrycia głowy były tam przygotowywane na potrzeby polskich produkcji filmowych. Drugi zakład modniarski wyrabia metodą tradycyjną (metoda naciągania) na zamówienia indywidualne kapelusze męskie i damskie. Wykonuje też różne, często nietypowe nakrycia głowy na potrzeby teatrów. Badane zakłady szewskie, używając tradycyjnych narzędzi, z reguły zajmują się naprawą używanego obuwia, a okazjonalnie również wykonywaniem obuwia na miarę, w tym obuwia ortopedycznego oraz specjalnego obuwia dla artystów. Z kolei, w obydwu badanych zakładach zegarmistrzowskich głównie dokonywane są naprawy zegarków i zegarów, w tym również starszych typów. Oferowana jest także sprzedaż niedrogich zegarków i budzików. Jednakże najbardziej popularną usługę stanowi sprzedaż oraz wymiana baterii i zakładanie pasków do zegarków. Jeden z zakładów specjalizuje się w naprawie zegarków szwajcarskich.

\section{Klienci badanych placówek usługowych oraz ich zachowania i opinie}

\section{Struktura demograficzno-społeczna klientów}

Sondażowe badania ankietowe klientów zanikających placówek usługowych w centrum Łodzi obejmowały 100 osób (Banaś 2013). Ich dobór miał charakter dostępnościowy, co ogranicza możliwości uogólnień uzyskanych wyników. Struktura demograficzno-społeczna badanych klientów wykazuje szereg specyficznych właściwości. W strukturze płci zaznacza się silna dominacja kobiet (186 kobiet na 100 mężczyzn), wynikająca $\mathrm{z}$ tradycyjnego podziału ról w gospodarstwie domowym. Najliczniejszą kategorię wiekową respondentów stanowią osoby od 30 do 50 lat (54\%), którym dokonywanie zakupu określonych usług z reguły ułatwia ustabilizowana sytuacja zawodowa i rodzinna (ryc. 5). Ponad to około 1/3 ankietowanych reprezentują osoby $\mathrm{w}$ wieku 50+, tradycyjnie korzystające $\mathrm{z}$ analizowanych usług. Natomiast stosunkowo nieliczną grupę usługobiorców $(12 \%)$ tworzą ludzie młodzi, liczący poniżej 30 lat, gdyż przedstawiciele tej grupy często preferują nowe rodzaje usług. $\mathrm{Z}$ uwagi na określoną wyżej strukturę wieku, większość respondentów (61\%) pozostaje w związkach małżeńskich (50\% w formalnych i 11\% w nieformalnych).

Zapotrzebowanie na rozpatrywane usługi korzystnie kształtuje dość wysoki poziom wykształcenia ankietowanych oraz ich specyficzna struktura głównych źródeł utrzymania i wykonywanych zawodów (Kramer 2000). Przeprowadzone badania wykazały, że ponad połowa respondentów (52\%) uzyskała wykształcenie średnie, a 1/5 (22\%) wyższe. Ponad 1/3 
(37\%) badanych prowadzi własną działalność gospodarcza, natomiast powyżej 1/4 (27\%) reprezentują pracownicy najemni. Głównym źródłem utrzymania dla 1/5 (20\%) badanych klientów były emerytury, renty, stypendia, zasiłki itp., a na utrzymaniu pozostawała blisko 1/10 (8\%) analizowanej populacji. Warto też zauważyć, że blisko 1/5 (18\%) ankietowanych była bez pracy. Struktura zawodowa respondentów jest bardzo silnie zróżnicowana, przy czym najwięcej z nich wykonuje zawód pracownika biurowego $(24 \%)$ oraz robotnika przemysłowego i rzemieślnika $(13 \%)$, a także operatora lub montera maszyn i urządzeń (9\%). Najczęściej z rozważanych usług korzystają osoby zaliczane do średniej grupy zawodów. Dodajmy, że ze względu na zawody wyuczone $1 / 3$ respondentów tworzą specjaliści, a ponad $1 / 4(27 \%)$ osoby bez zawodu, natomiast prawie $1 / 5$ $(17 \%)$ robotnicy przemysłowi i rzemieślnicy. Należy również podkreślić, że niemal połowa ankietowanych oceniła swoją sytuację materialną dobrze, a $40 \%$ - uznało ją za przeciętną.

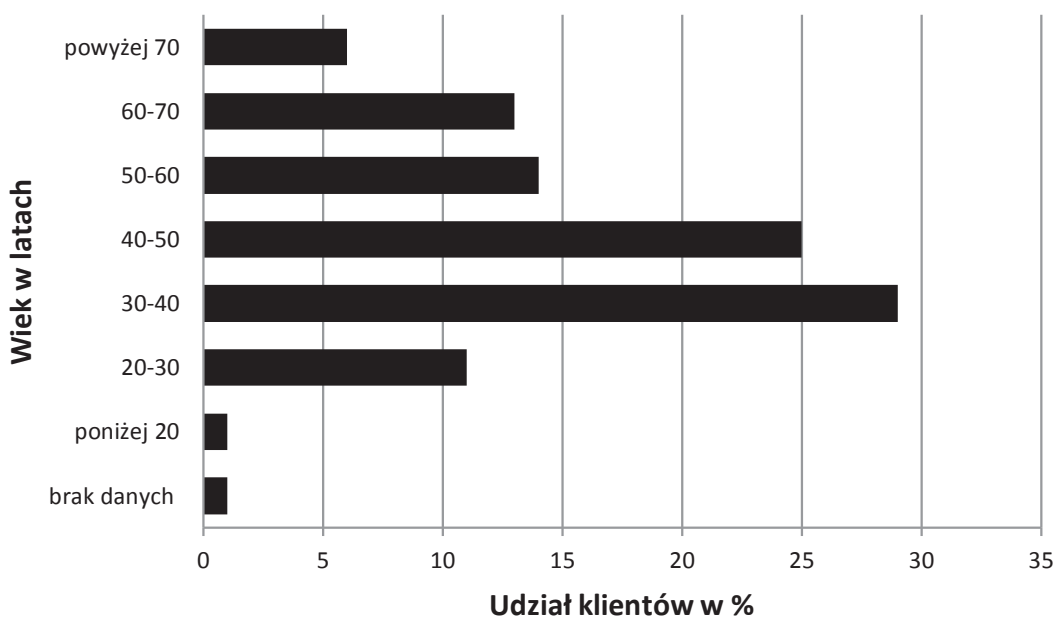

Ryc. 5. Struktura wieku badanych klientów zanikających placówek usługowych Źródło: materiały zebrane przez (Banaś 2013); opracowanie własne

\section{Zachowania zakupowe i przestrzenne klientów}

Jak wynika z analizowanych badań ankietowych, różnego rodzaju zanikające placówki usługowe w centrum Łodzi są odwiedzane przez klientów z odmienną częstotliwością (ryc. 6). Najczęściej korzystają oni z zakładów szewskich (67\% respondentów) i zegarmistrzowskich (52\%). Jedynie $30 \%$ respondentów korzysta z usług modystki, gorseciarki, krawca miarowego oraz czyszczenia i renowacji odzieży. Częstotliwość korzystania z określonych usług zanikających różnicuje się przy tym według płci i wie- 
ku klientów. Mężczyźni najczęściej korzystają z usług zegarmistrzowskich i szewskich, a w mniejszym stopniu z usług czyszczenia i renowacji odzieży oraz krawiectwa miarowego. W zasadzie nie odwiedzają oni ani zakładów gorseciarskich, ani modniarskich. Tymczasem kobiety częściej bywają w zakładach szewskich i zegarmistrzowskich, a rzadziej w zakładach krawieckich, gorseciarskich oraz zajmujących się czyszczeniem i renowacją odzieży. Najmniej kobiet korzysta z usług modystki. W poszczególnych grupach wiekowych najbardziej różnicuje się liczba klientów placówek czyszczenia i renowacji odzieży, gorseciarskich i krawiectwa miarowego. Natomiast niewielkim zróżnicowaniem tej liczby cechuje się szewstwo i zegarmistrzostwo. Większość respondentów korzysta dwa razy w roku z zakładów szewskich, a raz $\mathrm{w}$ roku z zakładów zegarmistrzowskich, czyszczenia i renowacji odzieży i krawiectwa miarowego.

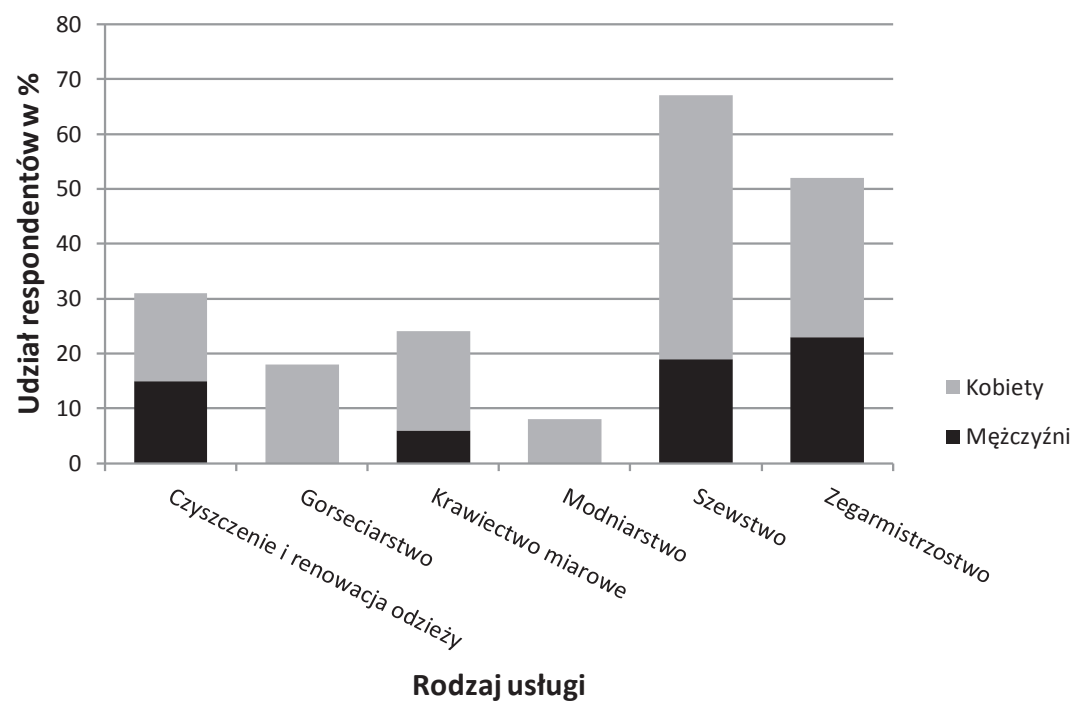

Ryc. 6. Korzystający z usług zanikających według płci Źródło: materiały zebrane przez (Banaś 2013); opracowanie własne

Badani klienci w ogromnej większości (70\%) pochodzą z samej Łodzi. Można przy tym zauważyć ich wyraźne skupienie w Śródmieściu oraz na terenie Radogoszczy-Łagiewnik, Starego Miasta i Retkini (ryc. 7). Znacznie mniej klientów pochodzi z Teofilowa-Żabieńca i Stoków-Nowosolnej, natomiast nie odnotowano w ogóle napływu klientów ze Złotna-Zdrowia. Stwierdzono również, że nieliczni klienci zamieszkują w miastach podłódzkich: Aleksandrowie Łódzkim, Pabianicach, Zgierzu, Tuszynie i Koluszkach. Przytoczone dane wskazują że na zasięg 
oddziaływania określonych placówek usługowych istotny wpływ ma ich odległość od miejsca zamieszkania klienta. Liczba klientów maleje wraz ze wzrostem tej odległości.

Większość respondentów (60\%) dojeżdża do badanych placówek usługowych samochodem. Ponad 1/5 (21\%) z nich korzysta w dojazdach do tych placówek z komunikacji miejskiej, a niewiele mniej (18\%) dochodzi do nich pieszo. Przeciętny czas dojazdu dla korzystających z samochodu wynosi 24 min., dla dojeżdżających środkami komunikacji miejskiej 28 min., natomiast w przypadku dochodzących pieszo tylko $14 \mathrm{~min}$.

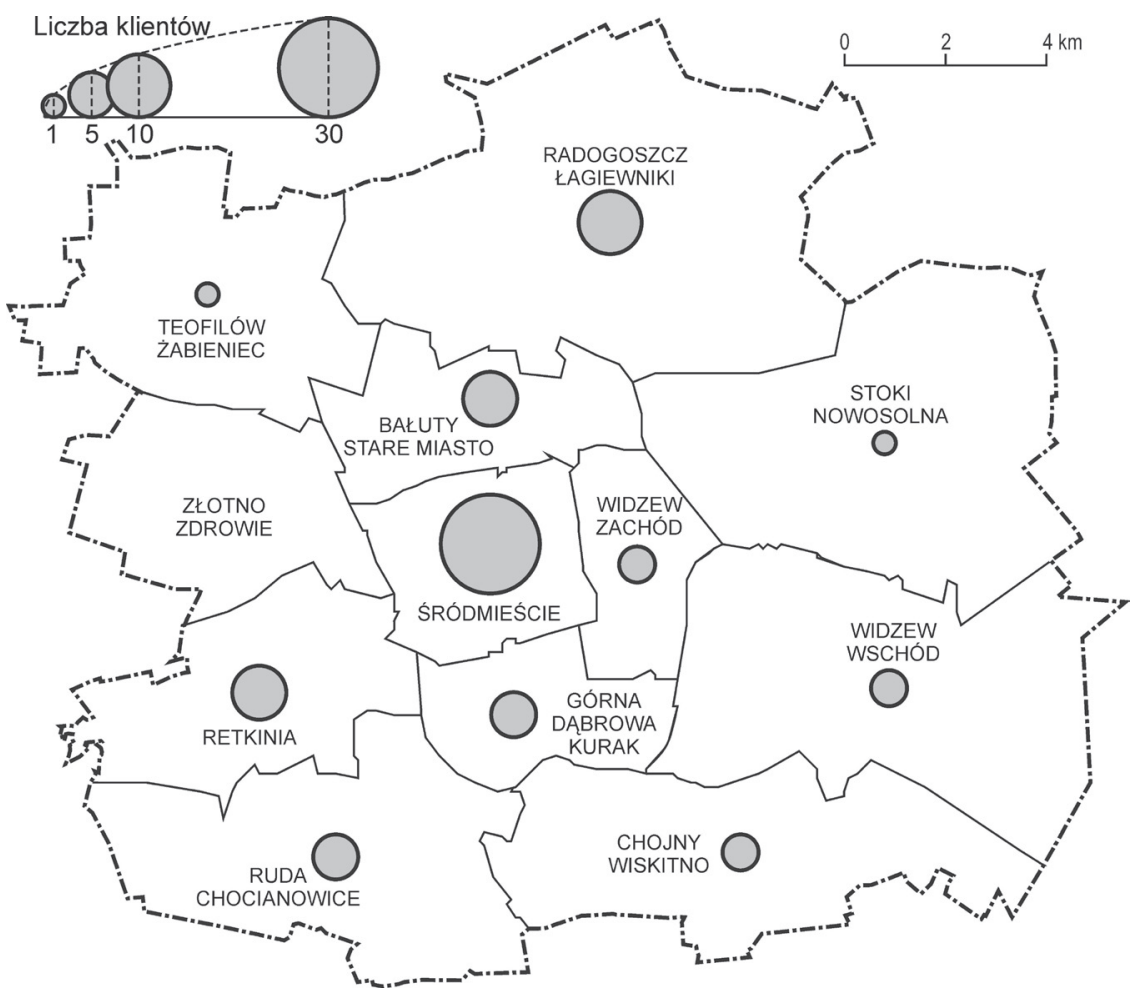

Ryc. 7. Rozmieszczenie badanych klientów zanikających placówek usługowych Źródło: materiały zebrane przez (Banaś 2013); opracowanie własne

\section{Opinie klientów o świadczonych usługach}

W toku omawianych badań ankietowych zebrane zostały opinie na temat przyczyn zanikania badanych usług, sposobów przeciwdziałania temu procesowi, jakości tych działalności usługowych i ich dostępności. Wskazywane przyczyny zanikania określonych usług były zróżnicowane. Do najczęściej wymienianych należą: niechęć młodzieży do nauki zawodów związanych z usługami zanikającymi (57\% respondentów), mały po- 
pyt na te usługi (52\%), zbyt duże ich koszty (49\%), mała dostępność (31\%), brak informacji o danych punktach usługowych (29\%) i brak zapotrzebowania (26\%) na ich usługi.

Warto również zauważyć, że ponad 3/4 respondentów uznało jednak potrzebę dalszego funkcjonowania zakładów świadczących usługi zanikające. Najczęściej były przy tym przytaczane następujące powody, uzasadniające taką postawę: istniejące zapotrzebowanie na takie usługi, ich dostępność dla osób gorzej sytuowanych, brak możliwości samodzielnego wykonania tego rodzaju usług, istnienie osób nietypowych, unikatowość takich usług, potrzeba kultywowanie ich tradycji. Respondenci wskazywali również różne sposoby zahamowania zanikania rozpatrywanych działalności usługowych. Do ważniejszych można zaliczyć: częstsze korzystanie $z$ danych usług (68\% respondentów), rozwój odpowiedniego szkolnictwa zawodowego (56\%), przeniesienie określonych punktów usługowych do centrów handlowych (55\%), poprawa warunków prowadzenia zanikającej działalności usługowej (43\%), uświadomienie społeczeństwu potrzeby przeciwdziałania zanikaniu tego typu usług.

Jakość świadczonych usług, ich asortyment i obsługa klientów w badanych zakładach usługowych zostały przez większość respondentów ocenione dobrze lub bardzo dobrze. Mniej niż 1/10 ankietowanych deklarowała średnie oceny przytoczonych cech usług, ale nikt nie sformułował ocen złych lub bardzo złych. Jednocześnie ceny tych usług przeważnie były oceniane jako przeciętne. Jedynie niecałe $10 \%$ badanych uznało te ceny za zbyt wysokie.

Do najwyżej cenionych cech punktu usługowego ankietowani zaliczyli: miłą obsługę (43\% respondentów), przystępne ceny usług (38\%), wysoką jakość usług (32\%), profesjonalizm obsługi (27\%), łatwy dostęp do placówki (22\%) i krótki czas realizacji usługi (18\%). Za mniej istotne cechy uznano: szeroki asortyment świadczonych usług (10\%), schludny wygląd placówki (9\%), lokalizację punktu usługowego blisko miejsca zamieszkania $(8 \%)$, dobrą reklamę (7\%) i dogodne godziny pracy $(3 \%)$.

\section{Podsumowanie}

Prezentowane wyniki badań dowodza, że przestrzeń aktywności ekonomicznej w Łodzi cechuje powolne zanikanie niektórych rodzajów usług oraz związanych z nimi placówek usługowych, miejsc pracy i wykonywanych zawodów. Należy przy tym podkreślić, że dochodzi do zanikania usług, które mają bogate tradycje historyczne. W tym opracowaniu szczegółowej analizie poddano, zlokalizowane w centrum Łodzi, takie usługi zanikające, wytypowane w toku sondażowych badań ankietowych, jak 
czyszczenie i renowacja odzieży, gorseciarstwo, krawiectwo miarowe, modniarstwo, szewstwo i zegarmistrzostwo.

Czynniki warunkujące lokalizację zanikających placówek usługowych w centrum Łodzi, wskazane przez ich właścicieli, są zbieżne z determinantami lokalizacji małych punktów usługowych w Warszawie, które zidentyfikował W. Wilk (2001). Główne kategorie tych czynników reprezentują dostępność komunikacyjną zanikających placówek handlowych, ich podaż, sytuację lokalowa, najbliższe otoczenie i inne warunki. W analizowanych wywiadach kwestionariuszowych najczęściej wskazywanymi czynnikami lokalizacji znikających usług były: łatwość dojazdu klientów środkami komunikacji miejskiej lub własnym samochodem i koszty utrzymania lokalu usługowego (dzierżawa, najem). Mniejszą wagę właściciele przywiązywali do bliskiego położenia własnego miejsca zamieszkania, dostępności miejsc parkingowych dla potrzeb własnych i klientów, jak też ogólnego stanu technicznego i wyposażenia budynku, w którym znajduje się siedziba zakładu usługowego.

Analizowane punkty usługowe są zlokalizowane w centrum Łodzi, gdzie dominuje funkcja usługowa. Jednocześnie tę część miasta wyróżnia ogromna intensywność zabudowy mieszkaniowej, bardzo duża gęstość ludności, a także sieci drogowej i linii komunikacyjnych. W bliskim

216 sąsiedztwie usług zanikających przeważnie występują lokale mieszkalne, a także różnego rodzaju usługi rynkowe. Natomiast rzadko sąsiedztwo to jest reprezentowane przez usługi nierynkowe. Tego rodzaju lokalizacja badanych placówek usługowych powinna wywierać korzystny wpływ na ich funkcjonowanie. W opinii właścicieli, do najważniejszych zalet lokalizacji tych placówek należą: położenie w tym samym miejscu od wielu lat, bliskie położenie przystanku komunikacji miejskiej, lokalizacja w centrum miasta, usytuowanie we frontowej części budynku oraz bliskie sąsiedztwo parkingu. Tymczasem do szczególnie ważnych wad lokalizacji zaliczano: położenie placówki usługowej w podwórzu, jej lokalizację na odcinku ulicy wyłączonym z ruchu, brak w zakładzie zaplecza higieniczno-sanitarnego, brak możliwości bezpośredniego dojazdu do zakładu.

Przeprowadzone badania dowiodły, że właścicieli określonych zakładów usługowych wyróżnia zrównoważona struktura płci, przy czym w większości należą oni do niemobilnej kategorii wieku produkcyjnego, co świadczy o zaawansowanym starzeniu demograficznym tej grupy społeczno-zawodowej. Przeważnie osiągnęli średnie lub wyższe wykształcenie i samodzielnie prowadzą swoje zakłady, przy czym wszyscy z nich są mieszkańcami Łodzi.

Rozpatrywane zakłady usługowe wyróżnia prosta aranżacja wnętrz, dostosowana do ich funkcji. Lokale usługowe zajmują niewielką powierzchnię, podzieloną zwykle na dwa odrębne, bardzo skromnie wy- 
posażone pomieszczenia, obejmujące część sprzedażową i zaplecze. Maszyny, urządzenia i narzędzia wykorzystywane w danych zakładach są przeważnie przestarzałe, a jakość stosowanych tam materiałów jest dostosowana do potrzeb klientów. Zakłady te $\mathrm{z}$ reguły nie zatrudniają pracowników najemnych, nie kształcą też uczniów w określonych zawodach. Wśród usługobiorców przeważają stali klienci, których liczba stopniowo maleje. Reklama świadczonych usług jest nadmiernie ograniczona. Poszczególne placówki usługowe od lat pełnią prawie te same wyspecjalizowane funkcje. Tylko sporadycznie ich oferta usługowa jest wzbogacana.

Sondażowe badanie ankietowe klientów zanikających placówek usługowych wskazuje na silną ich feminizację i bezwzględną dominację osób w wieku 30-50 lat. Respondentów wyróżnia dość wysoki poziom wykształcenia oraz specyficzna struktura źródeł utrzymania i wykonywanych zawodów. Ankietowani cechują się przy tym przewagą liczebną utrzymujących się ze źródeł zarobkowych i bardzo silnym zróżnicowaniem struktury zawodowej oraz najczęściej dobrą oceną własnej sytuacji materialnej.

Szczególny charakter mają zachowania zakupowe i przestrzenne badanej grupy klientów. Poszczególne zanikające punkty usługowe są przez nich odwiedzane $z$ różną częstotliwościa przy czym do najczęściej odwiedzanych należą zakłady szewskie i zegarmistrzowskie. Częstotliwość korzystania z określonych usług zanikających przez klientów jest zróżnicowana według ich płci i wieku, a liczebność usługobiorców, pochodzących w ogromnej większości z Łodzi, szybko maleje wraz ze wzrostem odległości ich miejsc zamieszkania od określonych placówek usługowych.

Opinie klientów o usługach świadczonych przez rozpatrywane zakłady usługowe są zróżnicowane. Jakość świadczonych usług, ich asortyment i obsługa w określonych zakładach zostały przez większość respondentów ocenione dobrze lub bardzo dobrze. Jednocześnie zdecydowana większość z nich wskazała na potrzebę dalszego funkcjonowania zakładów świadczących usługi zanikające.

W świetle przeprowadzonych badań, wszystkie analizowane rodzaje usług mają ograniczone możliwości dalszego funkcjonowania. Największe szanse na przetrwanie w przyszłości ma szewstwo i zegarmistrzostwo. Ożywienie rozwoju rozpatrywanych usług wymagałoby podjęcia następujących przedsięwzięć: zintensyfikowania działań marketingowych, opracowania programu lojalnościowego (np. programu rabatowego), połączenia danych zakładów z punktami przyjęć w placówkach handlowych, kioskach itp., otworzenia danego zakładu lub jego filii w centrach handlowych, zachęcenie młodzieży do kształcenia się $\mathrm{w}$ zawodach ginących, wspieranie zanikającej działalności usługowej przez samorządy oraz władze lokalne i centralne. 


\section{Literatura}

Banaś J. (2013), Usługi zanikajace w śródmieściu Łodzi, Katedra Gospodarki Przestrzennej i Planowania Przestrzennego UŁ, Łódź.

Baranowski B., Fijałek J. [red.] (1980), Łódź. Dzieje miasta, t. 1: Do 1918 r., PWN, WarszawaŁódź.

Boguszewicz-Kreft M. (2009), Zarządzanie doświadczeniem klienta w ustugach, Wyd. Uniwersytetu Gdańskiego, Gdańsk.

Budner W. (1999), Lokalizacja przedsiębiorstw, Akademia Ekonomiczna w Poznaniu, Poznań.

Budner W. (2004), Lokalizacja przedsiębiorstw; aspekty ekonomiczno-przestrzenne i środowiskowe, Akademia Ekonomiczna w Poznaniu, Poznań.

Czuba M. (2001), Marketing ustug. Teoria i praktyka, Wyd. Tara, Katowice.

Daszkowska M. (1998), Ustugi. Produkcja, rynek, marketing, Wyd. Naukowe PWN, Warszawa.

Dzieciuchowicz J. [red.] (2005), Ustugi rynkowe w Łodzi w dobie transformacji, Wyd. Uniwersytetu Łódzkiego, Łódź.

Dzieciuchowicz J.[red.] (2006), Ustugi nierynkowe w przestrzeni miejskiej Łodzi, Wyd. Uniwersytetu Łódzkiego, Łódź.

Dzieciuchowicz J. [red.] (2009), Ustugi dla producentów i biznesu w przestrzeni wielkomiejskiej. Przykład Łodzi, Wyd. Uniwersytetu Łódzkiego, Łódź.

Dzieciuchowicz J. (2011), Środowisko mieszkaniowe wielkiego miasta. Przykład Łodzi, Wyd. Uniwersytetu Łódzkiego, Łódź.

Dzieciuchowicz J. (2012), Wielkie centrum handlowe w przestrzeni miejskiej i podmiejskiej. Manufaktura w Łodzi i Ptak w Rzgowie, Wyd. Uniwersytetu Łódzkiego, Łódź.

218 Dzieciuchowicz J. (2013), Handel w przestrzeni wielkomiejskiej. Przykład Łodzi, Wyd. Uniwersytetu Łódzkiego, Łódź.

Dzieciuchowicz J. (2014), Ludność Łodzi. Rozwój i przemiany strukturalne, Wyd. Uniwersytetu Łódzkiego, Łódź.

Godlewska H. (2001), Lokalizacja działalności gospodarczej. Wybrane zagadnienia, Wyższa Szkoła Handlu i Finansów Międzynarodowych, Warszawa.

Godlewska H. (2005), Lokalizacja w zarzadzaniu przedsiębiorstwem, PW-H GRAF, Warszawa.

Ilnicki D. (2009), Przestrzenne zróżnicowanie poziomu rozwoju usług w Polsce. Teoretyczne i praktyczne uwarunkowania badań, Instytut Geografii i Rozwoju Regionalnego Uniwersytetu Wrocławskiego, Wrocław.

Jańczak M., Kasprzak M. (2008), Historia rzeczy codziennych, Wyd. MG, Warszawa.

Kramer T. (2000), Podstawy marketingu, PTE, Warszawa.

Liszewski S. [red.] (2009), Łódź. Monografia miasta, ŁTN, Łódź.

Mazurek-Łopacińska K. (2003), Zachowania nabywców i ich konsekwencje marketingowe, PWE, Warszawa.

Mikołajczyk B., Stolecka A. (2009), Wybrane aspekty zmian w ustugach w Polsce - diagnoza i prognoza, [w:] I. Rudawska, M. Soboń (red.), Przedsiębiorstwo i klient w gospodarce opartej na ustugach, Wyd. Difin, Warszawa.

Mrugalski Z. (2011), Historia zegarmistrzostwa w Polsce, Wyd. Naukowe ITE-PIB, Radom.

Rudawska I. [red.] (2009), Usługi w gospodarce rynkowej, PTE, Warszawa.

Rudnicki L. (2012), Zachowania konsumentów na rynku, PWE, Warszawa.

Sadowski T. (1997), Czyszczenie i renowacja odzieży futrzarskiej, Wyd. i Zakład Poligrafii ITE, Radom.

Skuza Z. A. (2012), Ginace zawody w Polsce, Wyd. Sport i Turystyka MUZA SA, Warszawa.

Szromik A. (2010), Marketing terytorialny. Miasto i region na rynku, Wolters Kluwer Polska, Warszawa. 
Usługi zanikające w przestrzeni wielkomiejskiej - przykład centrum Łodzi

Szulce H. (1998), Struktury i strategie w handlu, PWE, Warszawa.

Światowy G. (2006), Zachowania konsumentów, PWE, Warszawa.

Turnau I. (1983), Polskie skórnictwo, Zakład Narodowy im. Ossolińskich, Wrocław.

Wieloński A. (2004), Lokalizacja działalności gospodarczej. Teoretyczne podstawy, Wyd. Przemysłowe WEMA, Warszawa.

Wilk W. (2001), Czynniki lokalizacji i rozmieszczenie wybranych ustug w Warszawie, Wydział Geografii i Studiów Regionalnych Uniwersytetu Warszawskiego, Warszawa.

Williamson A., Mullin R. (2011), Field marketing. Skuteczne zastosowania marketingu terenowego, Wolters Kluwer Polska, Warszawa.

Woś J., Rachocka J., Kasperek-Hoppe M. (2011), Zachowania konsumentów - teoria i praktyka, Wyd. Uniwersytetu Ekonomicznego w Poznaniu, Poznań.

Jerzy Dzieciuchowicz, dr hab., profesor emerytowany, Katedra Studiów Ludnościowych i Badań nad Usługami, Uniwersytet Łódzki 